\title{
Assessment of the susceptibility of biomass to attempts at improving the durability of pellets
}

\section{Ocena podatności biomasy na próby poprawy wytrzymałości mechanicznej pelletów}

\author{
Jarosław Markowski
}

Oil and Gas Institute - National Research Institute

\begin{abstract}
The aim of the research was to determine one of the most important parameters of solid biomass fuel - mechanical strength - which is a measure of its resistance to conditions during transport and storage. For this purpose, five types of biomass were used in order to assess their susceptibility to an attempt at improving the durability of pellets produced from this biomass: pine sawdust, rapeseed cakes, flax cakes, rapeseed meal, and wheat bran. The organic and inorganic substances which were used as additives to improve the durability of the pellets included water glass, sugar, potato starch, calcium oxide, and calcium lignosulphonate. The durability tests were performed according to the PN-EN ISO 17831 method. The results of these tests showed that the biomass that is best for additizing is sawdust, though it only shows higher durability with the addition of selected additives. In the case of other types of biomass, it makes no sense to use any of the above-mentioned additives during the pelleting process. On the other hand, sugar and calcium lignosulphonate turned out to be the most efficient additives in terms of improving durability. Organic substances proved to be more efficient additives than inorganic substances. Measurements of the bulk density of the tested materials and the resulting pellets were also performed in order to determine the feasibility of the production of pellets. In the case of linseed cake and rapeseed meal, the increase in bulk density was so low that it did not justify the financial expenses necessary in this process.
\end{abstract}

Key words: biomass, pellet, mechanical strength, bulk density, durability.

STRESZCZENIE: W ramach przeprowadzonych badań stałego paliwa biomasowego dokonano oceny jednego z najważniejszych parametrów tego typu paliw - wytrzymałości mechanicznej, będącej miarą odporności na warunki panujące w trakcie transportu i przechowywania paliwa. W celu dokonania oceny podatności wybranych typów biomasy na próbę poprawy wytrzymałości mechanicznej uzyskanych z tej biomasy pelletów wykorzystano 5 rodzajów biomasy: trociny sosnowe, makuchy rzepakowe, makuchy lniane, śrutę rzepakową i otręby pszenne. Jako dodatki poprawiające wytrzymałość mechaniczną pelletów zastosowano substancje organiczne i nieorganiczne: szkło wodne, cukier, skrobię ziemniaczaną, tlenek wapnia i lignosulfonian wapnia. Badania wytrzymałości przeprowadzono według metody PN-EN ISO 17831. Wyniki tych badań wykazały, że biomasa, która najlepiej poddaje się uszlachetnieniu, to trociny - tylko one wykazują wyższą wytrzymałość mechaniczną po zastosowaniu wybranych dodatków uszlachetniających. W przypadku pozostałych rodzajów biomasy nie ma sensu stosowania w procesie pelletyzacji żadnego z wyżej wymienionych dodatków. Natomiast najskuteczniejszymi dodatkami poprawiającymi wytrzymałość mechaniczną, spośród badanych w tym projekcie, były cukier i lignosulfonian wapnia. Substancje organiczne okazały się skuteczniejszymi dodatkami niż substancje nieorganiczne. Najlepszą kombinacją biomasy i dodatków w badaniu były trociny z dodatkiem cukru lub lignosulfonianu wapnia - pomijając wynik otrzymany dla nieuszlachetnionych makuchów rzepakowych, takie kombinacje uzyskały dwa najlepsze wyniki pomiarów wytrzymałości. Przeprowadzono również pomiar gęstości nasypowej badanych surowców i otrzymanych pelletów w celu określenia celowości produkcji pelletów. W przypadku makuchów lnianych i śruty rzepakowej przyrost gęstości nasypowej był tak niski, że nie uzasadniało to poniesienia niezbędnych w tym procesie nakładów finansowych. Również wyniki pomiaru wytrzymałości mechanicznej otrzymanych z tych rodzajów biomasy pelletów były najgorsze spośród wszystkich badanych biomas, co dodatkowo podważa sens produkcji pelletów z takich surowców.

Słowa kluczowe: biomasa, pellet, wytrzymałość mechaniczna, gęstość nasypowa.

Corresponding author: J. Markowski, e-mail: jaroslaw.markowski@inig.pl

Article contributed to the Editor: 03.08.2020. Approved for publication: 02.12.2020 


\section{Introduction}

According to a European Directive, biomass refers to a biodegradable fraction of products, waste, or the remains of biological origin generated in agriculture (including plant and animal substances), silviculture, and associated industries - including fishing and aquaculture - as well as the biodegradable fraction of industrial and urban waste of biological origin (Directive 2009/28/EC). The potential energy resources of biomass can be divided into three groups by origin: biomass originating from trees, from agriculture, and from animals (Klimiuk et al., 2012; Niedziołka and Szpryngiel, 2014).

The energy stored in biomass can be released in several ways: by burning the biomass or by using it to produce liquid fuels or biogas, which can be subsequently used to produce thermal, mechanical, or electrical energy. Depending on the type of process for converting biomass into the final energy, the efficiency of this process ranges from $10 \%$ (for the generation of electrical power from biogas) to $90 \%$ (for the generation of thermal energy in the biomass combustion process) (Poland's energy policy until 2030, 2009; Huang and Zhang, 2011; Kołodziej and Matyka, 2012).

Most biomass used in Poland is solid, which in 2014 accounted for $97.91 \%$ of all heat originating from renewables (de Wit and Faaij, 2010) and 56.45\% of all electrical power generated from renewables (Klimiuk et al., 2012). A large portion of this biomass was used in the form of various types of pellets.

Also, the growing ecological awareness of society is causing pellets to grow in popularity among individual consumers, and the costs of operating heating boilers are comparable to other types of boilers used in households (Hamelinck and Faaij, 2006; How much is $1 \mathrm{kWh}, 2018$; Central Statistical Office, 2019).

Unprocessed plant biomass is characterised by low bulk density, making it harder to transport, store, and use in practice. This results in the need to densify it, e.g. into pellet or briquette form. These forms are produced from fragmented raw materials, dried to a suitable level as required by the manufacturer of the pelletising device, under high pressure and temperature, usually without the addition of any binders. During agglomeration, forces and the elevated temperature cause the raw material to thicken, which results in a drop in its water content, its mass concentration to increase, and therefore its energy density, as well as a considerable increase in the ease of distribution and use of this biofuel (Kołodziej and Matyka, 2012; Hejft, 2013).

The quality of pellets as determined by several physical properties, such as bulk density, heating value, durability, and water content, depends on the quality of the raw material and its production parameters.

One of the most important quality parameters related to pellets, for both the producer and the client, involves their durability, meaning the ability of the thickened biofuel to maintain its intact state during technological operations and transport. It is assessed according to the quality standard PN-EN ISO 17831.

In order to fulfil the requirements of customers, it may be necessary to use binding agents in the pellet production process (Marrero, 1999). Commonly used binders include substances of organic origin - made from plants or animals, so that their addition does not lower the biomass content of the fuel (Pietsch, 2002). Binders are added to biomass in a range of $0.5 \%$ and $5.0 \%$ by mass. The most frequently used organic additives of this type include lignin (Chin and Siddiqui, 2000; Li et al., 2018b), sulphonated lignin (calcium lignosulphonate) (Li et al., 2018b; Chin and Siddiqui, 2000), maize or potato starch (Obidziński, 2012; Obidziński et al., 2016), rye and wheat flour (Obernberger and Thek, 2004; Abedi et al., 2018), or sugar and molasses (Nikiema et al., 2013; Mišljenović et al., 2016).

Less common organic binders include a meal made from coffee beans or ground pine cones (Ahn et al., 2014). Additives constituting petroleum derivatives or inorganic compounds which can also be used as binders include coal tar (Cheng et al., 2018), water glass (Thomas et al., 1998), calcium oxide (Tabil et al., 1997; Kong et al., 2013), bentonite (Briggs et al., 1999), or gypsum (Kowalik, 2010; Kalembasa, 2017).

The dosage range of additives for improving the durability of pellets is between $0.5 \%$ and $5.0 \%$ by mass; however, the usual dosage amounts to $0.5-1.5 \%$ by mass due to the potential impact of the additives on the water content of the raw material used in the pellets, the impact on the heating value of the product, or the cost of certain substances used as additives (Ahn et al, 2014; Younis et al., 2018).

\section{Experimental part}

The substances used in the tests in order to improve the durability of pellets included table sugar (Südzucker SA), water glass (Dragon Poland Sp. z o.o. Sp. k.), burnt lime WR (calcium oxide; Lhoist Bukowa Sp. z o.o.), potato starch (PPZ Trzemeszno Sp. z o.o.), and calcium lignosulphonate (BorregaardLignoTech).

Additives were dispensed into the raw material in amounts equivalent to $1.0 \%$ by mass. Whenever necessary, solid substances were ground in order to homogenise the grains, which were dispensed in the form of a fine powder. Upon dispensing the additives, the samples were averaged and subsequently underwent the process of pelletisation.

The tests used the following types of biomass: rapeseed cakes, flax cakes, wheat bran, and rapeseed meal - produced by PHU Agrovet - as well as pine sawdust, produced by Biomasa Sp. z o.o.

The properties of these types of biomass are presented in Table 1. 
Table 1. Properties of the biomasses under study

Tabela 1. Właściwości użytej biomasy

\begin{tabular}{|l|c|c|c|c|c|}
\cline { 2 - 6 } & Pine sawdust & Wheat bran & Rapeseed cake & Linseed cake & Rapeseed meal \\
\hline \hline Moisture [wt \%] & 10.36 & 10.74 & 10.59 & 10.12 & 10.94 \\
\hline Volatiles [wt \%] & 71.63 & 45.83 & 67.31 & 74.25 & 73.46 \\
\hline Ash [wt \%] & 1.69 & 7.02 & 6.30 & 5.30 & 7.40 \\
\hline Fixed carbon [wt \%] & 16.33 & 31.71 & 15.80 & 10.33 & 8.20 \\
\hline Calorific value [MJ/kg] & 20.30 & 10.81 & 19.49 & 11.84 & 19.37 \\
\hline
\end{tabular}

Table 2. Bulk density of biomass before and after pelletisation

Tabela 2. Gęstość nasypowa biomasy przed i po pelletowaniu

\begin{tabular}{|l|c|c|c|c|c|}
\cline { 2 - 6 } \multicolumn{1}{c|}{} & Pine sawdust & Wheat bran & Rapeseed cake & Linseed cake & Rapeseed meal \\
\hline \hline Bulk density $\left[\mathrm{g} / \mathrm{cm}^{3}\right]$ & 0.147 & 0.263 & 0.444 & 0.603 & 0.598 \\
\hline Pellets bulk density $\left[\mathrm{g} / \mathrm{cm}^{3}\right]$ & 0.641 & 0.589 & 0.603 & 0.624 & 0.637 \\
\hline Bulk density increase $[\%]$ & 336.1 & 124.0 & 35.8 & 3.5 & 6.5 \\
\hline
\end{tabular}

The pellets were made in a ZLSP-150B device from Haven Polska Sp. z o.o. Approximately $3.0 \mathrm{~kg}$ of raw material were channelled each time through the device, heated up to its working temperature, and after cooling down, the resulting pellets were placed in a container which prevented them from absorbing moisture.

As mentioned above, one of the aims of pelletisation is to increase the density of the biomass in order to reduce the working volumes necessary for its transportation and storage. In order to confirm this hypothesis, bulk density measurements were performed for biomass (CN/TS 15103) in the state in which it was delivered (as received [AR]) and the in the resulting pellets; the results are presented in Table 2.

In all cases, the pelletisation of biomass resulted in an increase in its bulk density; however, as indicated by the data in Table 2, in the cases of flax cakes and rapeseed meal, pelletisation makes no economic sense, since the increase in bulk density through this process amounts to just $3.5 \%$ and $6.5 \%$, respectively. Considering the time, electricity, and effort necessary to produce the pellets, this is not justified.

The measurement of strength through a standardised method involves placing a sample of approximately $500 \mathrm{~g}$ of the pellets being tested inside a steel cuboid spinning at a velocity of $50 \mathrm{rpm}$, separating the fragmented pellets on a sieve with a mesh size of $3.15 \mathrm{~mm}$ after 10 minutes, and weighing the remains left on the sieve. The strength of the tested pellet sample can be calculated according to Equation 1. According to the quality standard, the standard deviation of results amounting to $\geq 97.5 \%$ is $0.3 \%$, while for results of $<97.5 \%$ it is $2 \%$. The results are presented in Table 3.

$$
D U=\left(\frac{m_{A}}{m_{E}}\right) \cdot 100 \%
$$

where:

$D U$ - durability [\%],

$m_{A}-$ mass of the sample after the test $[\mathrm{g}]$,

$m_{E}$ - mass of the sample before the test [g].

Unenhanced samples are characterised by the highest durability in four of the five types of biomass tested. Only in the case of sawdust can one see an improvement in strength after the use of additives, and in fact this is the only case where the use of enhancing additives is justified.

In order to compare the individual additives, their efficiency in increasing durability was determined for each type of biomass by rating them based on efficiency and creating a ranking of the tested additives, the results of which are presented in Table 4. The ranking was prepared in such a manner that for each type of biomass it was determined to what extent, if any, the enhancing additive improved the durability of pellets in relation to the unenhanced biomass, followed by scoring each additive between 5 points, for the most efficient additive, and 1 point, for the least efficient one. The efficiency of the additives was calculated for all types of biomass in this way.

The most efficient additives were sugar and calcium lignosulphonate; the worst results were produced with the use of inorganic additives: calcium oxide and water glass. An additional advantage of the best additives was the fact that they are substances of an organic origin, which does not cause as significant a decrease in the calorific value of the fuel as in the case of inorganic substances, nor does it lower the organic content of the fuel.

A similar method was used to prepare a ranking list of biomass types which are the most susceptible to enhancement by means of these types of additives, helping to demonstrate for which biomass it makes economic sense to use additives to improve its durability. The results are presented in Table 5. 
Table 3. The durability of the resulting pellets, according to PN-EN ISO 17831

Tabela 3. Wytrzymałość mechaniczna pelletów według PN-EN ISO 17831

\begin{tabular}{|c|c|c|}
\hline Type of biomass & Type of additive & Durability [\%] \\
\hline \multirow{6}{*}{ Rapeseed cake } & - & 98.53 \\
\hline & sugar & 77.26 \\
\hline & calcium lignosulphonate & 90.23 \\
\hline & water glass & 71.28 \\
\hline & potato starch & 68.13 \\
\hline & calcium oxide & 74.77 \\
\hline \multirow{6}{*}{ Pine sawdust } & - & 91.56 \\
\hline & sugar & 96.45 \\
\hline & calcium lignosulphonate & 96.99 \\
\hline & water glass & 87.33 \\
\hline & potato starch & 86.63 \\
\hline & calcium oxide & 92.37 \\
\hline \multirow{6}{*}{ Linseed cake } & - & 58.70 \\
\hline & sugar & 46.44 \\
\hline & calcium lignosulphonate & 51.45 \\
\hline & water glass & 43.01 \\
\hline & potato starch & 45.77 \\
\hline & calcium oxide & 46.28 \\
\hline \multirow{6}{*}{ Wheat bran } & - & 95.96 \\
\hline & sugar & 90.51 \\
\hline & calcium lignosulphonate & 90.73 \\
\hline & water glass & 91.42 \\
\hline & potato starch & 94.81 \\
\hline & calcium oxide & 74.56 \\
\hline \multirow{6}{*}{ Rapeseed meal } & - & 92.38 \\
\hline & sugar & 85.96 \\
\hline & calcium lignosulphonate & 85.58 \\
\hline & water glass & 79.96 \\
\hline & potato starch & 82.08 \\
\hline & calcium oxide & 76.44 \\
\hline
\end{tabular}

Table 4. The results of the evaluation of additives in terms of improving the durability of pellets

Tabela 4. Wyniki oceny skuteczności dodatków w poprawianiu wytrzymałości mechanicznej pelletów

\begin{tabular}{|c|c|}
\hline Additive & Position in the performance ranking \\
\hline \hline Sugar & 1 \\
\hline Calcium lignosulphonate & 1 \\
\hline Potato starch & 3 \\
\hline Calcium oxide & 4 \\
\hline Water glass & 5 \\
\hline
\end{tabular}

Table 5. The results of the evaluation of biomasses to additives for enhancing their durability

Tabela 5. Wyniki oceny podatności biomasy na poprawę wytrzymałości mechanicznej

\begin{tabular}{|c|c|}
\hline Biomass & Susceptibility to refinement \\
\hline \hline Pine sawdust & 1 \\
\hline Wheat bran & 2 \\
\hline Rapeseed cake & 3 \\
\hline Linseed cake & 3 \\
\hline Rapeseed meal & 5 \\
\hline
\end{tabular}

Sawdust constitutes the biomass which is best suited for enhancement; it is the type which exhibits the highest durability after the use of enhancing additives. For the remaining types of biomass, it makes no sense to use any of the above-mentioned additives in the pelletisation process.

\section{Conclusions}

The following can be concluded based on the research:

1. Of all biomass types tested in this study, pine sawdust is the one most affected by additives for improving durability; as for the remaining types of biomass, they demonstrated no improvement in this parameter, while in some cases the effect of additives was quite the opposite to the desired effect (deterioration of the durability of pellets).

2. Of all the additives tested in this project, sugar and calcium lignosulphonate turned out to be the most efficient ones in terms of improving durability. Organic substances proved to be more efficient additives than inorganic substances.

3. The above-mentioned conclusions indicate that the best combination of biomass and additives in the test would be sawdust with sugar or calcium lignosulphonate, which was indeed true (apart from the result involving unenhanced rapeseed cakes, such combinations produced the two top results of strength measurements).

4. The results of testing the bulk density of biomasses and pellets produced from them indicate that not in every case is the pelletisation process economically justified. In the case of linseed cake and rapeseed meal, the increase in bulk density was so low that it did not justify the financial expense necessary in this process. Also, the results of durability measured for pellets generated from these types of biomass were the worst of all tested biomass types, which additionally undermines the sense of producing pellets from these types of raw materials. 
The paper was written on the basis of the statutory work entitled: Wplyw lepiszczy na wytrzymałość pelletów otrzymywanych z różnego typu biomasy - the work of the Oil and Gas Institute - national Research Institute was commissioned by the Ministry of Science and Higher Education; order number: 0016/TC/2019, archive number: DK-4100-0008/2019.

\section{References}

Abedi A., Cheng H., Dalai A.K., 2018. Effects of Natural Additives on the Properties of Sawdust Fuel Pellets. Energy \& Fuels, 32: 1863-1873. DOI: 10.1021/acs.energyfuels.7b03663.

Ahn B.J., Chang H., Lee S.M., 2014. Effect of binders on the durability of wood pellets fabricated from Larix kaemferi C. and Liriodendron tulipifera L. sawdust. Renewable Energy, 62: 18-23. DOI: 10.1016/j. renene.2013.06.038.

Briggs J.L., Maier D.E., Watkins B.A., 1999. Effects of ingredients and processing parameters on pellet quality. Poultry science, 78: 1464-1471. DOI: 10.1093/ps/78.10.1464.

Central Statistical Office, 2019. Energy from renewable sources in 2018. <stat.gov.pl/en/topics/environment-energy/energy/energy-from-renewable-sources-in-2018,3,9.html $>$ (access: 24.04.2020).

Cheng J., Zhou F., Si T., 2018. Mechanical strength and combustion properties of biomass pellets prepared with coal tar residue as a binder. Fuel Processing Technology, 179: 229-237. DOI: 10.1016/j. fuproc.2018.07.011.

Chin O.C., Siddiqui K.M., 2000. Characteristics of some biomass briquettes prepared under modest die pressures. Biomass and Bioenergy, 18: 223-228. DOI: 10.1016/j.biombioe.2009.07.011.

de Wit M., Faaij A., 2010. European biomass resource potential and costs. Biomass Bioenergy, 34: 188-202.

Hamelinck C.N., Faaij A.P.C., 2006. Outlook for advanced biofuels. Energy Policy, 34: 3268-3283. DOI: 10.1016/j.enpol.2005.06.012.

Hejft R., 2013. Innowacyjność w granulowaniu biomasy. Czysta energia, 6: 130, 32-34.

How much is $1 \mathrm{kWh}$ ?, 2018 Summary of costs for obtaining $1 \mathrm{kWh}$ from various energy sources. $<$ http://www.pieniadzepodkontrola.pl/ ile-kosztuje-kwh-kilowatogodzina-zestawienie-kosztow-uzyskania1kwh-z-roznych-zrodel-energii> (access: 24.06.2020).

Huang W.D., Zhang Y.P., 2011. Energy efficiency analysis: biomassto-wheel efficiency related with biofuels production, fuel distribution, and powertrain systems. PLoS One, 6: e22113. DOI: 10.1371/ journal.pone.0022113.

Kalembasa D., 2017. Ecological fuel from vegetal biomass for ovens. Patent PL 224648.

Klimiuk E., Pawłowska M., Pokój T., 2012. Biopaliwa. Technologie dla zrównoważonego rozwoju. Wyd. Naukowe PWN, Warszawa.

Kołodziej B., Matyka M., 2012. Odnawialne źródła energii. Rolnicze surowce energetyczne. Wyd. PWRiL, Poznań.

Kong L., Tian S.H., Li Z., 2013. Conversion of recycled sawdust into high HHV and low NOx emission bio-char pellets using lignin and calcium hydroxide blended binders. Renewable energy, 60: 559-565. DOI: 10.1016/j.renene.2013.06.004.

Kowalik S., 2010. Energy briquettee. Patent PL 207093.

Li W., Jiang Y., Rao S., 2018a. Parameter optimization of corn stover blended with sawdust and sodium lignosulphonate compression experiments. Transactions of the Chinese Society of Agricultural Engineering, 34: 198-203. DOI: 10.11975/j. issn.1002-6819.2018.01.027.

Li W., Jiang Y., Yin X., 2018b. Characterization of Hydrolysis Lignin Bonding Properties During the Pelletization of Eucalyptus Sawdust, Waste Biomass Valorization, 1-9.

Marrero T.R., 1999. Theory and application of binders: an update. Proceedings of Institute for Briquetting and Agglomeration (IBA), 26: $103-109$.
Mišljenović N., Čolović R., Vukmirović D., 2016. The effects of sugar beet molasses on wheat straw pelleting and pellet quality. A comparative study of pelleting by using a single pellet press and a pilot-scale pellet press. Fuel Processing Technology, 144: 220-229. DOI: 10.1016/j.fuproc.2016.01.001.

Niedziołka I., Szpryngiel M., 2014. Możliwości wykorzystania biomasy na cele energetyczne. Inżynieria Rolnicza, 1: 155-164. DOI: 10.14654/ir.2014.149.017.

Nikiema J., Cofie O., Asante-Bekoe B., 2013. Potential of locally available products for use as binders in producing fecal compost pellets in Ghana. Environmental Progress \& Sustainable Energy, 33: 504-511. DOI: 10.1002/ep.11790.

Obernberger I., Thek G., 2004. Physical characterization and chemical composition of densified biomass fuels with regard to their combustion behavior. Biomass and Bioenergy, 27: 653-669. DOI: 10.1016/j.biombioe.2003.07.006.

Obidziński S., 2012. Analysis of usability of potato pulp as solid fuel. Fuel Processing Technology, 94: 67-74. DOI: 10.1016/j. fuproc.2011.10.012.

Obidziński S., Piekut J., Dec D., 2016. The influence of potato pulp content on the properties of pellets from buckwheat hulls. Renewable Energy, 87: 289-297. DOI: 10.1016/j.renene.2015.10.025.

Peng J., Bi X.T., Lim C.J., 2015. Sawdust as an effective binder for making torrefied pellets. Applied Energy, 157: 491-498. DOI: 10.1016/j. apenergy.2015.06.024.

Pietsch W., 2002. Agglomeration processes - phenomena, technologies, equipment. Wyd. Wiley-VCH, Weinheim.

Poland's energy policy until 2030, 2009. <https://www.gov.pl/documents/33372/436746/DE Zalacznik nr 2 Prognoza zapotrzebowania na paliwa $\mathrm{i}$ energie-ost.pdf $/ 5 \mathrm{~d} 4 \mathrm{c}$ efd 2 -fd64-f871-a537f93c19b342e2> (access: 24.06.2020).

Tabil Jr. L.G., Sokhansanj S., Tyler R.T., 1997. Performance of different binders during alfalfa pelleting. Canadian Agricultural Engineering, 39: 17-23.

Thomas M., van Vliet T., van der Poel A.F.B., 1998. Physical quality of pelleted animal feed 3. Contribution of feedstuff components. Animal Feed Science and Technology, 76: 59-78. DOI: 10.1016/ S0377-8401(97)00072-2.

Younis M., Alnouri S.Y., Abu Tarboush B.J., 2018. Renewable biofuel production from biomass: a review for biomass palletization, characterization and thermal conversion techniques. International Journal of Green Energy, 15: 837-863. DOI: 10.1080/15435075.2018.1529581.

\section{Legal and normative acts:}

CN/TS 15103: Solid Biofuels. Methods for determination of bulk density. Directive 2009/28/EC of the European Parliament and of the Council of 23 April 2009 on the promotion of the use of energy from renewable sources and amending and subsequently repealing Directives 2001/77/EC and 2003/30/EC.

PN-EN ISO 17831-1:2016-02 Solid biofuels - Determining the mechanical strength of pellets and briquettes - Part 1: Pellets.

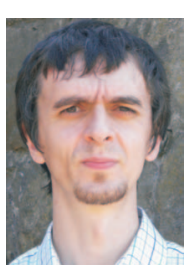

Jarosław MARKOWSKI M.Sc. Eng.

Assistant at the Department of Additives and New Chemical Technologies

Oil and Gas Institute - National Research Institute 25 A Lubicz St.

31-503 Krakow

E-mail: jaroslaw.markowski@inig.pl 